\title{
PARASITOLOGY
}

EDITED BY

- GEORGE H. F. NUTTALL, F.R.S.

Quick Professor of Biology in the University of Cambridge

ASSISTED BY

EDWARD HINDLE, Рн.D.

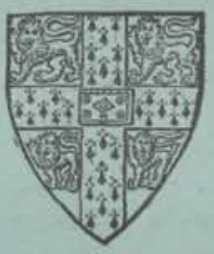

CAMBRIDGE UNIVERSITY PRESS

C. F. CLAY, MAsagen

LONDON: FETTER LANE, E.C. 4

Anso

H. K. LEWIS AND CO., LTD., 136, GOWER STREKr, LONDON, W.c. 1

WHIIAS WESLEY AND BON, 28, ESSEX STHEET, STRAND, LONDON, W.C. 2 OHCAGO; THE UNTVEISTTY OY CHCAGO PRESS

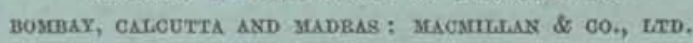

TORONTO: J. A. DENT AND SONS, LTD.

TOKYO: THE MTABUZEN-KABUSHIKT-KATSHA

Price Twelve Shillings and Sixpence net 


\title{
$\mathrm{ON}$
}

\section{GROWTH AND FORM}

BY

\section{D'ARCY WENTWORTH THOMPSON,}

$$
\text { C.B., D.Litt., F.R.S. }
$$

Professor of Natural History in University College,

Dundee, University of St Andrews; Scientific

Member of the Fishery Board for Scotland

Demy 8vo. pp. xvi +794 . With 408 illustrations. Price 21 net.

"Professor Thompson has written an interesting and valuable book on a topic of enduring interest. Why does the animal kingdom present to us a picture of such infinite variety, variety in size and shape, in external appearance, and in the minutest details of internal anatomy? And why, running through the diversities, are there so many resemblances ?...... The purposes of Professor Thompson's book is to explain the 'must be' of structure." - Times

\section{Prospectus on application}

\section{CAMBRIDGE UNIVERSITY PRESS}

Fetter Lane, London, E.C. 4 : C. F. Clay, Manager

\section{THE JOURNAL OF \\ ZOOLOGICAL RESEARCH}

(Founded 1905 as "The Journal of Economic Biology")

\author{
EDITED BY \\ WALTER E. COLLINGE, \\ D.Sc. (St And.), M.Sc. (Birm.), F.L.S., etc. \\ Research Fellow of the University of St Andrews.
}

A quarterly periodical for the publication of records of original research in systematic and structural zoology.

Fully illustrated by lithographic plates and text-figures.

Each volume will consist of four parts, price 215.

All editorial communications should be addressed to

Dr Walter E. Collinge, the University, St Andrews and all subscriptions to

London: Dulau \& Co., Ltd., 37, Soho Seuare, W. I 


\section{PARASITOLOGY}




\section{CAMBRIDGE UNIVERSITY PRESS}

C. F. CLAY, Manager

LONDON: FETTER LANE, E.C. 4

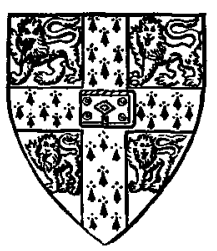

H. K. LeWIS \& co., LTD., 136, GOWER STREeT, LONDON, W.c. I WILLIAM WESLEY \& SON, 28 , ESSEX STREET, LONDON, W.C. 2 CHICAGO: THE UNIVERSITY OF CHICAGO PRESS BOMBAY, CALCUTTA, MADRAS: MaCMILLAN \& CO., LTD. TORONTO: J. M. DENT \& SONS, LTD. TOKYO: THE MARUZEN-KABUSHIKI-KAISHA 


\title{
PARASITOLOGY
}

\author{
EDITED BY \\ GEORGE H. F. NUTTALL, F.R.S. \\ QUICK PROFESSOR OF BIOLOGY IN THE UNIVERSITY OF CAMBRIDGE \\ ASSISTED BY \\ EDWARD HINDLE, Ph.D.
}

VOLUME X 1917-18

\author{
CAMBRIDGE \\ AT THE UNIVERSITY PRESS
}




\section{CONTENTS}

\section{No. 1 (November, 1917)}

Nutrall, G. H. F. Bibliography of Pediculus and Phthirus, including Zoological and Medical Publications dealing with Human Lice, their Anatomy, Biology, Relation to Disease, etc., and Prophylactic Measures directed against them . . . . . .

Nuttali, G. H. F. The Part played by Pediculus humanus in the Causation of Disease. (With Plate I)

PAGE

Nuttali, G. H. F. The Biology of Pediculus humanus. (With Plates II and III and 12 Text-figures) . . . . . . . .

HowletT, F. M. Notes on Head- and Body-Lice and upon Temperature Reactions of Lice and Mosquitoes

\section{No. 2 (JANUARY, 1918)}

Stewart, F. H. On the Development of Ascaris lumbricoides and A. mystax in the Mouse. (With Plate IV) . . . . 189

Stewart, F. H. On the Life History of Ascaris lumbricoides L. . . 197

Walton, Chas. L. Some Results of a Survey of the Agricultural Zoology of the Aberystwyth Area . . . . . .

WaLton, Chas. L. Liver Rot of Sheep, and Bionomics of Limnaea truncatula in the Aberystwyth Area. (With 5 Text-figures) . . 232

Weidman, Fred D. A Contribution to the Anatomy and Embryology of Cladorchis (Stichorchis) subtriquetrus Rudolphi, 1814 (Fischoeder, 1901). (With Plate $\mathrm{V}$ and 2 Text-figures) . . . . . .

BAcot, A. A Note on the period during which the Eggs of Stegomyia fasciata (Aëdes calopus) from Sierra Leone Stock retain their vitality in a Humid Temperature . . . . . . 
Warbupton, Cecil. Notes on Ticks. (With 3 Text-figures)

Nicoll, William. On the Occurrence of Hydatid Cysts in Monkeys . 288

Nicold, William. Dolichopera macalpini n. sp., a Trematode Parasite of Australian Poisonous Snakes . . . . . . . . . 290

Dobeli, Clifford. Are Entamoeba histolytica and Entamoeba ranarum the same Species?

No. 3 (APRIL, 1918)

Gilchrist, J. D. F. The Life History of Distoma luteum n. sp., with Notes on some Cercariae and Rediae found in S. Africa

Dobell, Clifford, and Jepps, Margaret, W. A Study of the Diverse Races of Entamoeba histolytica distinguishable from one another by the dimensions of their Cysts. (With 7 Text-figures and Plate VI) . . . . . . . . . . .

Jeprs, Margaret W., and Dobell, Cinfford. Dientamoeba fragilis n. g., n. sp., a new Intestinal Amoeba from Man. (With Plate VII)

Nicoll, Wilitam. The Trematode Parasites of North Queensland.

IV. Parasites of Reptiles and Frogs. (With Plate VIII) . . 368

Nuttald, George H. F. The Pathological Effects of Phthirus pubis .

Nuttall, George H. F. The Biology of Phthirus pubis. (With 9 Textfigures)

KeILIN, D. On the occurrence of a Cephaline Gregarine, Leidyana tinei $\mathrm{n}$. sp., in Lepidopterous larvae. (With 1 Text-figure and Plate IX)

\section{No. 4 (MAY, 1918)}

Nuttall, George H. F. Combating Lousiness among Soldiers and Civilians. (With Plates $\mathrm{X}-\mathrm{XIII}$ and 26 Text-figures). . 